DOI 10.22460/infinity.v6i2.p95-110

\title{
MATHEMATICAL LITERACY'S VOCATIONAL STUDENTS BASED ON LOGICAL AND NUMERICAL REASONING
}

\author{
Lathifatun Ni'mah ${ }^{1}$, Iwan Junaedi ${ }^{2}$, Scolastika Mariani ${ }^{3}$ \\ ${ }^{1}$ SMK NU Lasem, Jl. Sunan Bonang KM 01 Lasem Rembang, Jawa Tengah, Indonesia \\ ${ }^{2,3}$ Semarang State University, Jl. Sekaran, Gunung Pati, Kota Semarang, Jawa Tengah, Indonesia \\ ${ }^{1}$ nlathifatun@yahoo.co.id
}

Received: March 03, 2017 ; Accepted: May 01, 2017

\begin{abstract}
The research aims is (1) to obtain learning quality of CTL model to students mathematical literacy, (2) to obtain mathematical literacy description based on logical reasoning, (3) to obtain mathematical literacy description based on numerical reasoning and (4) to obtain mathematical literacy description based on logical and numerical reasoning. The research type is descriptive study. The subject is XI AK SMK NU Lasem were taken 6 students high, medium and low logical reasoning, 6 students high, medium, and low numerical reasoning, 6 students high, medium, and low logical and numerical reasoning, 2 students high logical and medium numerical reasoning, 2 students medium logical and high numerical reasoning. The research result is (1) CTL models learning quality for mathematical literacy is good, (2) student mathematical literacy based on high logical reasoning level 4 and 5, medium level 3, low level 1 and 2, (3) student mathematical literacy based on high numerical reasoning level 5, medium level 4, low level 2 and 3, (4) student mathematical literacy based on high logical and numerical reasoning level 5, medium level 3 and 4, high logical and medium numerical reasoning or medium logical and high numerical reasoning level 4 and 5, low level 1 and 2.
\end{abstract}

Keywords: CTL, logical reasoning, mathematical literacy ability, numerical reasoning.

\begin{abstract}
Abstrak
Penelitian bertujuan untuk (1) memperoleh gambaran kualitas pembelajaran model CTL terhadap kemampuan literasi matematika, (2) memperoleh gambaran literasi matematika ditinjau dari penalaran logis, (3) memperoleh gambaran literasi matematika ditinjau dari penalaran numerik dan (4) memperoleh gambaran literasi matematika ditinjau dari penalaran logis dan numerik. Jenis penelitian ini adalah penelitian deskriptif. Subjek penelitian adalah siswa XI AK SMK NU Lasem diambil 6 orang kategori penalaran logis tinggi, sedang, dan rendah, 6 orang penalaran numerik tinggi, sedang, dan rendah. 6 orang penalaran logis dan numerik rendah, sedang, tinggi, 2 orang penalaran logis tinggi dan numerik sedang, serta 2 orang penalaran logis sedang dan numerik tinggi. Hasil penelitian menunjukkan bahwa (1) kualitas pembelajaran model CTL terhadap kemampuan literasi matematika berkategori baik, (2) literasi matematika siswa penalaran logis tinggi mencapai level 4 dan 5, sedang level 3, dan rendah level 1 dan 2, (3) literasi matematika siswa penalaran numerik tinggi pada level 5, sedang level 4, serta rendah level 2 dan 3, (4) literasi matematika siswa penalaran logis dan numerik tinggi level 5, sedang level 3 dan 4, logis tinggi dan numerik sedang maupun logis sedang dan numerik tinggi level 4 dan 5, serta rendah level 1 dan 2.
\end{abstract}

Kata Kunci: CTL, kemampuan literasi matematika, penalaran logis, penalaran numerik.

How to Cite: Ni'mah, L., Junaedi, I. \& Mariani, S. (2017). Mathematical Literacy's Vocational Students Based on Logical and Numerical Reasoning. Infinity, 6 (2), 95-110. doi:10.22460/infinity.v6i2.p95-110 


\section{INTRODUCTION}

Quality of education in Indonesia is currently low. This is consistent with the results of research Rusmining, Waluya, \& Lewis (2014) that Indonesia has a low education quality based on the results of the acquisition of Indonesian students at the international ratings (international assessment). One of the factors Indonesian students score low are Indonesian students trained solve the problems that substance PISA and TIMSS contextual, demanding reasoning, argumentation and creativity to solve them poorly (Wardhani and Rumiati, 2011).

Mathematics and mathematical reasoning are two things that can not be separated (Ministry of Education in Shadiq, 2004). Math is believed can increase the power of reason (Kariadinata, 2012). Human reasoning is also needed when troubleshooting problems or when the decision making process (the US president Thomas Jefferson in Shadiq, 2004). Reasoning is one indicator of literacy (Turner, 2011). "Problem solving, reasoning, and numeracy is one of the EYFS areas of learning and development" (Adonis, 2006).

Studying mathematics literacy is one of the prerequisites for someone to be successful in the 21st century (Murnane, Sawhill \& Snow, 2012). Some activities that can encourage literacy math is (1) reasoning mathematically and mathematical concepts, (2) recognizing the role that mathematics plays in the world, (3) making well-founded judgments and decisions, (4) solving problems set in the pupil's life world context (Sandstorm, Nilsson \& Lilja, 2013). "Four interrelated thinking processes items, namely problem solving, representating, manipulating and reasoning underpin mathematical literacy" (Pugalee in Diezmann, Watters \& English, 2001). This means that the reasoning underlying the mathematical literacy skills. The results of the Diezmann, Watters \& English (2001) also mentions that four thought process on equal influence on mathematics literacy.

Bokar (2013) argues that today's students should be given the problems associated with the real world to prepare students to be able to resolve the issue properly in accordance with logical and mathematical reasoning. Durrant-Law (2013) argued that logic is the philosophical study of valid reasoning. By the time students complete the real problem is given, there is a process that includes phases employing mathematical concepts, facts, prosedures, and reasoning (Stacey, 2012). According to Venkat, Graven, Lampen \& Nalube (2009), two factors suggested as the central development of the literacy skills are mathematical reasoning (reasoning) and problem solving (problem solving). For more Venkat, Graven, Lampen \& Nalube (2009) also stated that the needed in the reasoning is numerical and spatial thinking. Therefore, the point of logical and numerical reasoning is needed to be studied.

There are several learning models are suitable for reasoning. Based on Shadiq (2004) learning theory that fits with reasoning are RME, PBL, and CTL. CTL subject matter associated with real life / simulation (Mulyatiningsih, 2010). CTL characteristics include, among others Relating, Experiencing, Applying, Cooperating, and Transferring (COR in Kasihani, 2002). 
Based on background that has been described, there are several point of this research: (1) How is the quality of the CTL model learning mathematics literacy class XI student of SMK? (2) How does the literacy skills math class XI student of SMK based on logical reasoning? (3) How does the literacy skills math class XI student of SMK based on numerical reasoning? and (4) How does the literacy skills math class XI student of SMK based on logical and numerical reasoning?

\section{METHOD}

This type of research is qualitative descriptive study. The research was conducted at SMK NU Lasem AK XI classes in the second semester of the academic year 2014/2015. Results of tests of mathematical literacy skills of students were analyzed and deepened by interviewing the subject of research as triangulation. For mathematical literacy test using adoption mathematical literacy test from south africa 2014.

In this study, reasoning (reasoning) is the activity of thinking to draw conclusions or make new statements and was based on some statements whose truth has been proven or assumed before (Shadiq, 2004). Definition of logical reasoning in this study is an activity for the reasons, decide to accept and reject information, and explain the idea (Dowden, 2011). The principles of logical reasoning has been put forward by Dowden (2011) are (1) to find out the underlying reasons before accepting a conclusion, (2) provide arguments supporting the conclusion, (3) revealed the reasons underlying the decision making, (4) design reasons which implies the conclusion, (5) introduce the importance of relevant information, (6) the pros and cons, (7) to consider possible actions, (8) to see the consequences of various actions which do, (9) evaluate the consequences, (10) consider if the consequences actually occurred, (11) delaying decision-making in the state of practice, (12) to assess what was said in the actual situation, (13) to avoid judging someone literally, (14) using background knowledge and sense healthy to draw conclusions, (15) given that remarkable statement requires extraordinary evidence, (16) put off asking an expert, (17) given that firm conclusions require strong reasons, (18) consistent reasoning oneself, (19) looking for inconsistencies reasoning oneself and others, (20) check some explanation that fits all the facts, (21) to make explanations others less so calculated by showing alternative explanations are taken into account, (22) reasoning adapted to the subject, and (23) draw conclusions if've got enough evidence.

Logical reasoning ability is measured using Kenexa Logical Reasoning Test (LRT). Measuring numerical reasoning skills students used numerical reasoning by Paul Newton and Helen Bristoll. Reasoning can be classified into 3 groups: (1) a group of high reasoning: the value $\geq \bar{x}+1 s d$, (2) a group of medium reasoning $\bar{x}-1 s d \leq$ value $<\bar{x}+1 s d$, (3) groups of low reasoning the value $<\bar{x}-1$ sd (Suherman and Sukjaya in Riyanto \& Siroj, 2011). Logical reasoning can be classified into 3 groups: (1) a group of logical reasoning high the value $\geq \bar{X}+1 s d$, (2) groups of logical medium reasoning $\bar{X}-1 s d \leq$ value $<\bar{X}+1 s d$ : (3) a group of low logical reasoning the value $<\bar{X}-1 s d$ : as well as numerical reasoning can 
be classified into 3 groups: (1) a group of high numerical reasoning the value $\geq \bar{X}+1 s d$, (2) groups of medium numerical reasoning $\bar{X}-1 s d \leq$ value $<\bar{X}+1 s d$, (3) groups of low numerical reasoning the value $\geq \bar{X}+1 s d$.

According Ojose (2011) mathematical literacy is the ability of students to be able to understand and apply some math applications such as facts, principles, operations, and problem solving in everyday life in the past and also the present. Mathematical literacy skills in this study is the individual's ability to formulate, employ, and interpret mathematics in various contexts (OECD, 2013). Some aspects related to mathematical literacy based on the OECD (2013) are as follows.

(1) The mathematical processes that describe what individuals do to connect the context of the problem with mathematics and thus solve the problem, and the capabilities that underlie those processes.

(2) The mathematical content that is targeted for use in the assessment items.

(3) The context in which the assessment items are located.

Table 1. Proportion Score Sub-sub Process Components Tested in the PISA study (OECD, 2013)

\begin{tabular}{clc}
\hline Component & \multicolumn{1}{c}{ Ability Tested } & Score (\%) \\
\hline Process & Formulating situations mathematically & 25 \\
& $\begin{array}{l}\text { Employing mathematical concept, facts, } \\
\text { pocedures and reasoning }\end{array}$ & 50 \\
& $\begin{array}{l}\text { Interpreting, applying, and evaluating } \\
\text { mathematical outcomes }\end{array}$ & 25 \\
\hline
\end{tabular}

There are fundamental mathematical capabilities that include in mathematical processes. The fundamental mathematical capabilities are communicating, mathematising, representation, reasoning and argument, Devising strategies for solving problems, Using symbolic, formal and technical language and operations, and Using mathematical tools. Fomulating include it, employing and interpreting too.

Table 2. Proportion Score Sub-sub Process Content Components Tested in the PISA study (OECD, 2013)

\begin{tabular}{clc}
\hline Component & \multicolumn{1}{c}{ Ability Tested } & Score (\%) \\
\hline Content & Space and shape & 25 \\
& Change and Relationship & 25 \\
& Quantity & 25 \\
& Uncertainty and Data & 25 \\
\hline
\end{tabular}


Table 3. Proportion Score Sub-sub Process Context Components Tested in the PISA study (OECD, 2013)

\begin{tabular}{llc}
\hline Component & \multicolumn{1}{c}{ Context understanding } & Score $(\boldsymbol{\%})$ \\
\hline Context & Personal & 25 \\
& Occupational & 25 \\
& Societal & 25 \\
& Scientific & 25 \\
\hline
\end{tabular}

Table 4. Mathematics literacy level based on PISA (OECD, 2013)

\begin{tabular}{ll}
\hline \multicolumn{1}{c}{ Level } & \multicolumn{1}{c}{ Student activity } \\
\hline Level $6(\geq 669,3)$ & $\begin{array}{l}\text { Students can conceptualise, generalise and utilise information } \\
\text { based on their investigations and modelling of complex } \\
\text { poblem situations. They can link different information }\end{array}$ \\
& sources and representations and flexibility translate among \\
& them. Students capable of advanced mathematics thinking \\
& and reasoning. These students can apply their insight and \\
& understandings along with a mastery of symbolic and formal \\
& mathematical operations and relationship to develop new \\
& appoaches and strategies for attacking novel situations. \\
& Students at this level can formulate an precisely \\
& communicate their actions and reflections regarding their \\
findings, interpretations, arguments and the appropriateness \\
of these to the original situations.
\end{tabular}

Level $5(\geq 607,0) \quad$ Students can develop and wok with models for complex situation, identifying constraints and specifying assumptions. They can select, compare and evaluate appopriate poblemsolving strategies for dealing with complex problems related to these models. Students at this level can work strategically using broad, well-developed thinking and reasoning skills, appropriate linked representations, symbolic and fomal characterisations and insight pertaining to these situations. They can reflect on their actions and formulate and communicate their intepretations and reasoning.

Level $4(\geq 544,7) \quad$ Students can work effectively with explicit models for complex concrete situations that may involve constraints or call for making assumptions. They can select and intergrate different representations, including symbolic, linking them directly to aspects of real wold situations. Students at this level can utilities well-developed skills and reason flexibly, with some insight, in these context. They can construct and communicate explanations and arguments based on their interpretations, arguments and actions. 


\begin{tabular}{|c|c|}
\hline Level & Student activity \\
\hline Level $3(\geq 482,7)$ & $\begin{array}{l}\text { Students can execute clearly described pocedures, including } \\
\text { those that require sequential decisions. They can select and } \\
\text { apply simple problem-solving strategies. Students at this } \\
\text { level can interpret and use representations based on different } \\
\text { infomation sources and reason directly from them. They can } \\
\text { develop short communications when reporting their } \\
\text { intepretations, results and reasoning. }\end{array}$ \\
\hline Level $2(\geq 420,1)$ & $\begin{array}{l}\text { Students can interpret and recognise situations in context that } \\
\text { require no more than direct inference. They can extract } \\
\text { relevant information from a single source and make use of a } \\
\text { single expresentational mode. Students at this level can } \\
\text { employ basic logaithms, formulae, pocedures, or } \\
\text { conventions. They are capable of direct reasoning and } \\
\text { making literal interpretations of the results. }\end{array}$ \\
\hline Level $1(\geq 357,8)$ & $\begin{array}{l}\text { Students can answer questions involving familiar context } \\
\text { where all relevant infomation is present and the questions are } \\
\text { clearly defined. They are able to identify information and to } \\
\text { carry out routine procedures according to direct instructions } \\
\text { in explicit situations. They can perform actions that are } \\
\text { obvious and follow immediately from the given stimuli. }\end{array}$ \\
\hline
\end{tabular}

Determination of the subjects in this study based on the result of logical and numerical reasoning tests using kenexa test and numerical reasoning tests from Paul Newton and Helen Bristoll. This study took two students from each of the test results of logical and numerical reasoning. Students as research subjects are 2 students with low logical reasoning scores, 2 students with medium logical reasoning scores, 2 students with high logical reasoning scores, 2 students with low numerical reasoning scores, 2 students with medium numerical reasoning scores, 2 students with high numerical reasoning scores, and if there are students have same level of logical and numerical reasoning will be examined too. 2 students with low logical and numerical reasoning scores, 2 students with medium logical and numerical reasoning scores, 2 students with high logical and medium numerical reasoning scores, 2 students with medium logical and high numerical reasoning scores, as well as 2 students with high logical reasoning and numerical scores.

\section{RESULTS AND DISCUSSION}

Some domains from Charlotte Danielson's Framework for measuring the success of learning, those are (1) planning and preparation, (2) classroom environment, (3) instruction, dan (4) professional responsibilities (MacGregor, 2007). Krause, Dias, \& Schedler (2015) said that there are 7 aspect fo measuring leaning quality (1) competencies and learning activities, (2) assessment and evaluation, (3) learning sources, (4) technology aand navigation, (5) learner support, (6) accessibility, dan (7) policy compliance. From them, the aspects are assessed on the quality of learning include preparation, process, and evaluation. During the preparation stage includes three dimensions: the device (syllabus, lesson plans, worksheets, LTS, 
supplement teaching materials, materials (uncertainty), and assessment (assessment tools). Stage of the process also consists of three dimensions: competencies and learning activities, learning resources, using technology (related to learning media). Evaluation stage consists of tests of mathematical literacy (TKLM).

The preparation phase on the quality of learning consulted to the lecturers through several revisions. Learning device that be prepared covering are syllabus, lesson plans, worksheets, LTS, supplement teaching materials, and assessment tools.

Table 5. Result Preparation Learning tools

\begin{tabular}{cll}
\hline No. & \multicolumn{1}{c}{ Aspect } & \multicolumn{1}{c}{ Criteria } \\
\hline 1. & Syllabus & Good and can be used \\
2. & Lesson Plan & Good and can be used \\
3. & Worksheet & Good and can be used \\
4. & LTS & Good and can be used \\
5. & Supplement Teaching Materials & Good and can be used \\
6. & Assesment Tools & Good and can be used \\
\hline
\end{tabular}

At the process stage including the competence and learning activities, learning resources, using technology (related to learning media) that used to help math teacher SMK NU Lasem. There are three teachers who observed Eny Handayani, S.Pd., Sunawan, S.Pd., And Sri Winarti, S.Pd. The results of the observations made by three teachers mentioned that the learning process with CTL model categorized good (average score of quationare is 3). In accordance with the results of Melville \& Yaxley (2009) which states that one of the model that can make pofessional learning is contextual learning. The following are observations about the learning process.

Table 6. Result Process Learning

\begin{tabular}{ccc}
\hline No. & Observer & Score (criteria) \\
\hline 1. & Observer 1 & 3,32 (good) \\
2. & Observer 2 & 3,59 (good) \\
3. & Observer 3 & 3,41 (good) \\
\hline
\end{tabular}

Based on the results of research conducted by Suyono (2009) indicating that literacy based on effective and productive learning can improve the quality of learning and graduate school. TKLM results indicate that there are 2 students who achieve level 1, 2 students at level 2, 5 students level 3, 7 students at level 4, 2 students have reached level 5, and no student who reaches level 6.

Table 7. List of Subjects Research By Category Logical Reasoning

\begin{tabular}{cc}
\hline Logical Reasoning Category & Student (TKLM Score) \\
\hline High & E1 $(639,8)$, E21 $(579,3)$ \\
Medium & E15 $(523,9)$, E16 $(518,9)$ \\
Low & E3 $(370,3)$, E8 $(435,8)$ \\
\hline
\end{tabular}


The results from the study showed that the literacy skills of mathematics students with high category logical reasoning that the subject E1 $(639,8)$ and E21 $(579,3)$ which have respectively reached level 5 and level 4. This is consistent with the results of research Bokar (2013) indicating that the student should be given the problems associated with the real world to prepare students to be able to solve the problem well in accordance with the logical and numerical reasoning. Subject E1 and E21 able to do the formulating problem with basic capabilities of communicating, representation, and devising strategies for problem solving. In general, E1 and E21 can do the employing problem with basic capabilities of mathematising, representation, reasoning and argument, devising strategies for problem solving, using symbolic, formal and technical language and operations, and using mathematics tools. For the process of interpreting the subject E1 and E21 has been completed perfectly with basic capabilities of communicating, representation, and devising strategies for problem solving.

On the subject matter 5.2.2.d E1 and E21 have been able to solve employing problems with basic capabilities category mathematising. This suitable with interview result that both of them understand and can solve the problem:

5.2.2 Pak Rudi memberi tugas matematika pada siswanya untuk melakukan survei banyaknya uang saku siswa laki-laki dan perempuan kelas XI AK yang dihabiskan selama istirahat makan siang di sekolah pada hari tertentu.

Banyaknya uang saku siswa laki-laki yang telah di survei

\begin{tabular}{llllllll}
\hline 9.000 & 10.000 & 10.000 & 12.000 & 12.000 & 12.000 & 12.000 & 12.000 \\
\hline 14.000 & 15.000 & 15.000 & 16.000 & 18.000 & 20.000 & 25.000 & \\
\hline \multicolumn{7}{c}{ Banyaknya uang saku siswa } & perempuan yang telah di survei \\
\hline 0 & 6.000 & 6.000 & 9.000 & 9.000 & 10.000 & 10.000 & 10.000 \\
\hline 11.000 & 11.000 & 11.000 & 11.000 & 12.000 & 20.000 & 25.000 & 30.000 \\
\hline
\end{tabular}

5.2.2.d Hitunglah median uang yang dihabiskan oleh siswa perempuan

E1:

E22:
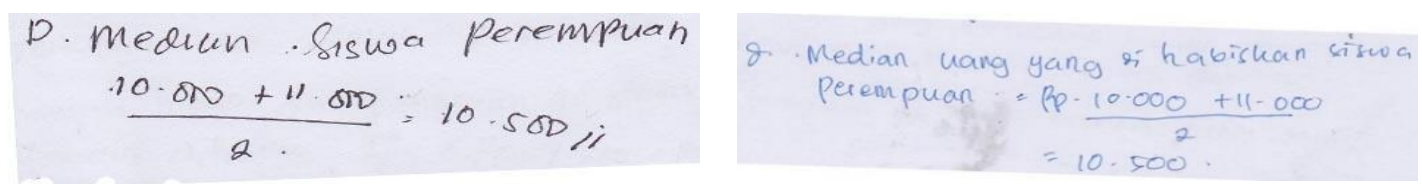

Figure 1. Sample Results Subject E1 and E21 for Employing Problem with Category Mathematizing Number 5.2.2.d

Subject E15 (523,9, level 3) and E16 (518,9, level 3) is already able to do formulating problems with basic of capabilities communicating, representation, and devising strategies for problem solving. In the process of the subject Employing E15 and E16 have been able to solve problems with basic capabilities of communicating, representation, devising strategies for solving problems, and using mathematics tools. If viewed from the process of interpreting the subject of E15 and E16 already completed perfectly communicating problems with basic capabilities of representation and reasoning and argument. In interview both of them said that they can not operate mathematical model in 3.2.4. 
On 3.2.4 E15 and E16 have not been able to solve employing problems with basic capabilities category mathematising.

3.2.4 Pada tahun 2010, laju pertumbuhan penduduk Indonesia adalah $1.49 \%$. Tentukan populasi Indonesia pada tahun 2000 jika populasi pada tahun 2010 adalah 237.641.326.

Presentase pertumbuhan $=\frac{(\text { populasi 2010-populasi 2000) }}{\text { populasi } 2000} \times 100 \%$

E15:

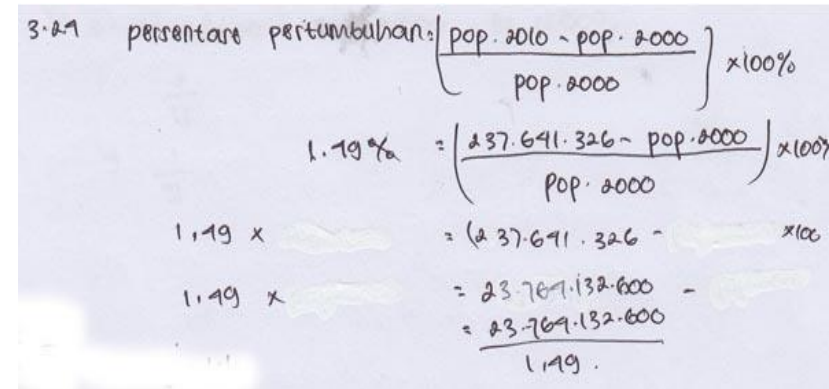

E16:

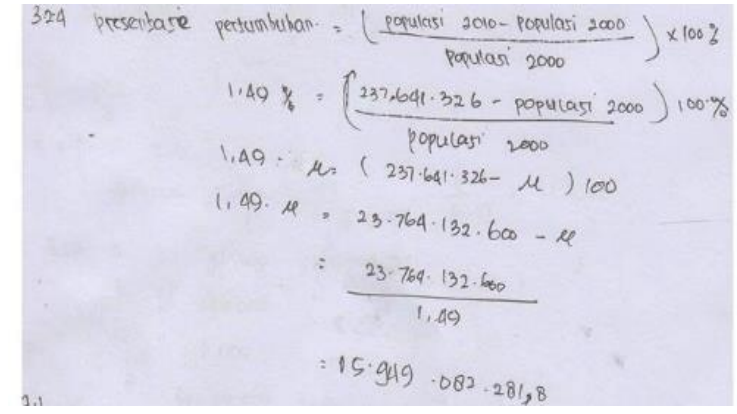

Figure 2. Sample Results Subject E15 and E16 for Employing Problems with Basic Capabilities Category Mathematizing Number 5.2.2.d

Mathematics literacy skills of students with lower category logical reasoning indicates that the subject chosen E3 $(370,3)$ and E8 $(435,8)$ respectively reached level 1 and level 2 . When viewed from category formulating, Employing, and interpreting the subject of E3 and E8 are only able to work on the problems with basic capabilities communicating.

On 3.1.7 E3 and E28 have not been able to solve employing problems with basic capabilities category mathematizing. Interview result write that for E3 can not rounding number but E8 do not understand to calculate probability.

3.1 Tabel di bawah ini menunjukkan informasi dari profil 2014 penduduk Indonesia.

\begin{tabular}{llcc}
\hline & & Simbol & Persentase \\
\hline Islam & Islam & $\mathrm{I}$ & 87,2 \\
Non Islam & Kristen & $\mathrm{Kr}$ & 6,9 \\
& Katolik & $\mathrm{Kt}$ & 2,9 \\
& Hindu & $\mathrm{H}$ & 1,7 \\
& Buddha & $\mathrm{B}$ & 0,7 \\
& Konghucu & $\mathrm{Kc}$ & 0,05 \\
\hline
\end{tabular}

3.1.7. Jika dipilih secara acak penduduk Indonesia hitunglah peluang terpilihnya orang beragama Hindu?

E3:

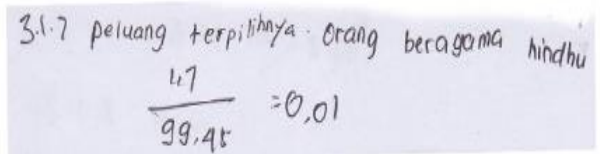

E8:

No answer

Figure 3. Sample Results Subject E3 and E8 for Employing Problems with Basic Capabilities Category Mathematizing Number 3.1.7 
Table 8. List of Subjects Research By Category Logical Reasoning

\begin{tabular}{cc}
\hline Numerical Reasoning Category & Student (TKLM Score) \\
\hline High & E1 $(639,8)$ \\
Medium & E4 $(566,7)$, E13 $(569,2)$ \\
Low & E20 $(478,6)$, E22 $(493,7)$ \\
\hline
\end{tabular}

Mathematics literacy skills of students with high numerical reasoning category indicates that the subject E1 been reached level 5. Subject E1 has been able to do formulating problem with the basic capabilities of communicating, mathematising, representation, reasoning and argument, devising strategies for problem solving, using symbolic, formal and technical language and operations, and using mathematics tools. When viewed from employing problem E1 has been able to solve problems with basic capabilities of communicating, representation, reasoning and argument, devising strategies for problem solving, and using symbolic, formal and technical language and operation. In the process of interpreting the subject E1 has been completed perfectly with basic capabilities of communicating, mathematising, representation, using symbolic, formal and technical language and operations, and using mathematics tools.

The results showed that mathematics literacy skills of students with medium numerical reasoning the subject E4 and E13 which have both reached level 4. Subject E4 and E13 is already able to do the problems formulating with basic capabilities of communicating, mathematising, reasoning and argument, devising strategies for problem solving, using symbolic, formal and technical language and operations, and using mathematics tools. Based on a review of the employing problem E4 and E13 have been able to solve problems with basic capabilities of communicating. In the process of interpreting the subject of E4 and E13 has been completed perfectly problem with basic capabilities of mathematising, representation, using symbolic, formal and technical language and operations, and using mathematics tools.

On 3.1.7 E4 and E13 have not been able to solve employing problems with basic capabilities category mathematizing. E4 clarify that she does not read problem correctly but for E13 still difficult in rounding.

3.1.7 Jika dipilih secara acak penduduk Indonesia hitunglah peluang terpilihnya orang beragama hindu?

E4:

E13:

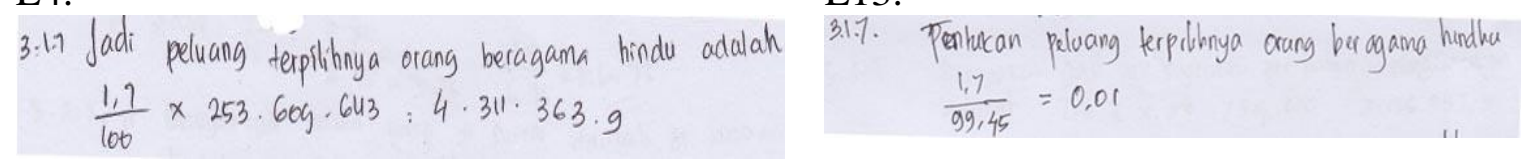

Figure 4. Sample Results Subject E4 and E13 for Employing Problems with Basic Capabilities Category Mathematizing Number 3.1.7

Subject E20 (478,6, level 2) and E22 (493,7, level 3) is already able to do formulating problems with basic capabilities of mathematising, representation, reasoning and argument, using symbolic, formal and technical language and operations, and using mathematics tools. Based on a review of the employing problem E20 and E22 have been able to solve problems 
with basic capabilities of communicating, and representation. In the process of interpreting the subject of E20 and E22 already completed perfectly with basic capabilities of mathematising, using symbolic, formal and technical language and operations, and using mathematics tools. For clarification both of them said that they can not operate mathematical model in 3.2.4.

Examples of the work of a low numerical reasoning subject matter of numbers 3.2.4.

E20:

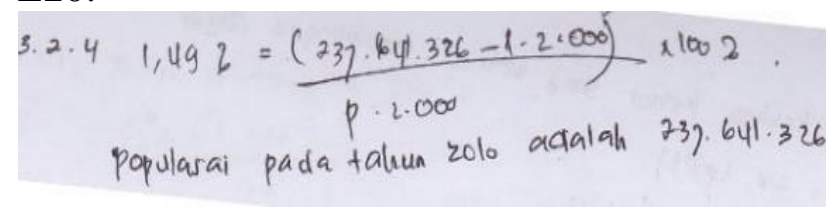

E22:

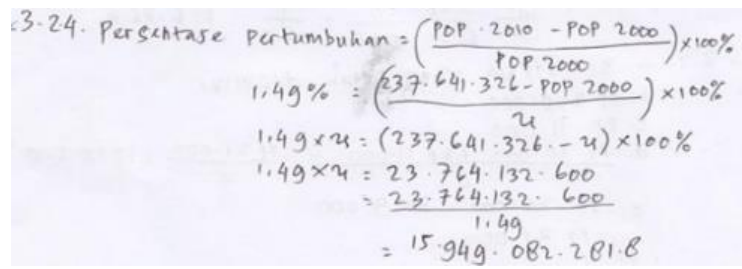

Figure 5. Sample Results Subject E20 and E22 for Employing Problems with Basic Capabilities Category Mathematizing Number 3.2.4

Table 9. List of Subjects Research By Category Logical and Numerical Reasoning

\begin{tabular}{cccc}
\hline $\begin{array}{c}\text { Reasoning } \\
\text { Category }\end{array}$ & $\begin{array}{c}\text { High Numeric } \\
\text { (TKLM score) }\end{array}$ & $\begin{array}{c}\text { Medium Numeric } \\
\text { (TKLM score) }\end{array}$ & $\begin{array}{c}\text { Low Numeric } \\
\text { (TKLM score) }\end{array}$ \\
\hline High Logic & E1 (639,8) & E21 (579,3) & - \\
Medium Logic & E14 $(619,6)$ & E16 $(518,9)$, E19 $(604,5)$ & - \\
Low Logic & - & - & E3 $(370,3)$, E20 478,6$)$ \\
\hline
\end{tabular}

Subject E1 (level 5) has been able to do about formulating problem with basic capabilities of communicating, mathematising, representation, reasoning and argument, devising strategies for problem solving, using symbolic, formal and technical language and operations, and using mathematics tools. Based on a review of the subject E1 Employing been able to solve problems with basic capabilities of communicating, representation, reasoning and argument, devising strategies for problem solving, and using symbolic, formal and technical language and operation. In the process of interpreting the subject E1 has been completed perfectly with basic capabilities communicating, mathematising, representation, using symbolic, formal and technical language and operations, and using mathematics tools.

Subject E16 (level 3) and E19 (level 4) is already able to do formulating problems with basic capabilities of communicating, mathematising, representation, reasoning and argument, devising strategies for problem solving, using symbolic, formal and technical language and operations, and using mathematics tools. Employing the process of the subject on the E16 and E19 have been able to solve problems with basic capabilities of communicating, and representation. In the process of interpreting the subject of E16 and E19 are already solving problems with basic capabilities of communicating, mathematising, representation, using symbolic, formal and technical language and operations, and using mathematics tools.

For number 3.1.7 E16 and E19 have not been able to solve employing problems with basic capabilities category mathematizing. In interview E16 said that she does not read problem correctly but for E19 still difficult in rounding. 
E16:

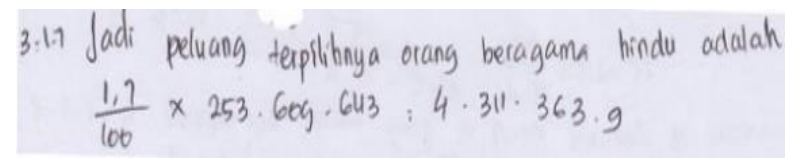

E19:

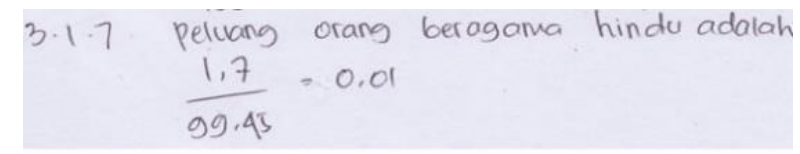

Figure 6. Sample Results Subject E16 and E19 for Employing Problems with Basic Capabilities Category Mathematizing Number 3.1.7

Subject E14 (level 5) and E21 (level 4) capable of doing a matter of formulating with basic ability of communicating, mathematising, representation, reasoning and argument, devising strategies for problem solving, using symbolic, formal and technical language and operations, and using mathematics tools. Based on a review of the subject Employing E14 and E21 have been able to solve problems with basic capabilities of communicating, and representation. In the process of interpreting E14 and E21 are already solving problems with basic capabilities of communicating, mathematising, representation, using symbolic, formal and technical language and operations, and using mathematics tools.

Examples of the work of E14 and E21 for number 3.2.4. For clarification they said that can not operate mathematical model in 3.2.4.
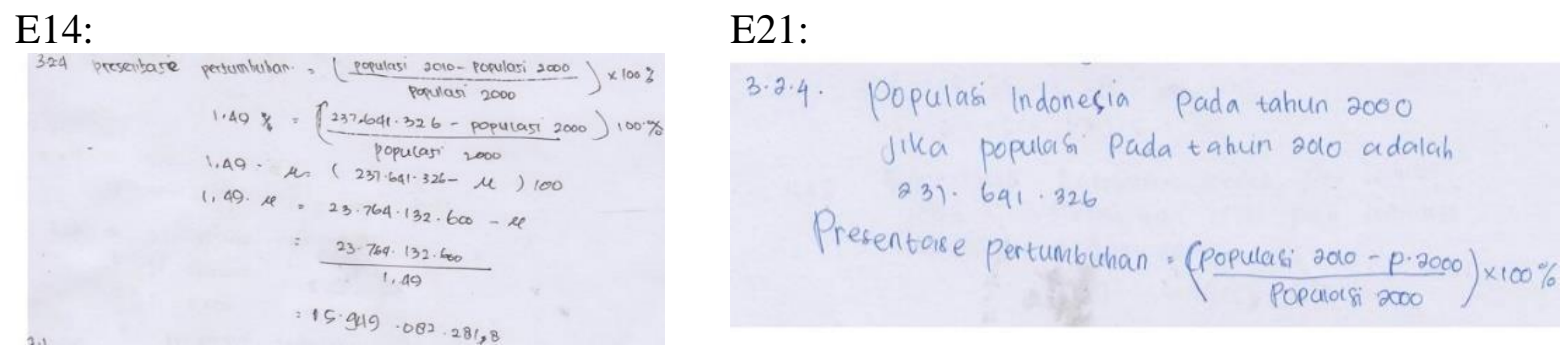

Figure 7. Sample Results Subject E14 and E21 for Employing Problems with Basic Capabilities Category Mathematizing Number 3.2.4

Subject E3 (level 1) and E20 (level 2) is already able to do the problems formulating with basic capabilities of mathematising, representation, reasoning and argument, using symbolic, formal and technical language and operations, and using mathematics tools. E3 and E20 able to solve employing problem only with basic capabilities of communicating. Based on a review of the process of interpreting the subject of E3 and E20 already solving the basic capabilities of mathematising, using symbolic, formal and technical language and operations, and using mathematics tools.

For number 3.1.7 E3 and E20 have not been able to solve employing problem with basic capabilities category mathematizing. In interview process E3 said that still difficult with rounding but E20 not read corectly in this poblem. 
Problem : Number 3.1.7

Answer E3:

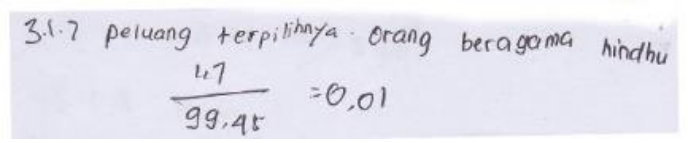

Answer E20:

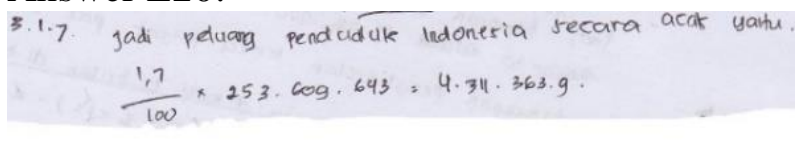

Figure 8. Sample Results Subject E3 and E20 for Employing Problems with

Basic Capabilities Category Mathematizing Number 3.1.7

\section{CONCLUSION}

Based on the result of data analysis, the conclusions are:

1. The quality of learning with CTL model towards mathematics literacy for student grade XI of SMK categorized well. This is indicated in the preparatory phase learning device consultated to the supervisor through several revisions categorized good and can be used. At this stage of the process based on the observation of math teacher SMK NU Lasem good category. In the evaluation phase are two students reached level 1, 2 students at level 2, 5 students at Level 3, 7 students on level 4, and 2 students at level 5.

2. Literacy mathematical vocational students of class XI based on logical reasoning is: a) Students with high logical reasoning achieving level 4 and 5, good in formulating with communicating, representation, and devising strategies for problem solving, for employing with communicating, mathematising, representation, reasoning and argument, devising strategies for problem solving, using symbolic, formal, and technical language and operation, and using mathematics tools and fo interpreting with communicating, representation, and devising strategies for problem solving; b) Students with medium logical reasoning reached level 3 , good in fomulating with communicating, representation, and devising strategies for problem solving, employing with communicating, representation, devising strategies for solving problems, and using mathematics tools, and intepreting with communicating, representation, dan reasoning and argument; c) Students with low logic at level 1 and 2, good in formulating, employing and interpreting with communicating.

3. The ability of the mathematical literacy of students based on numerical reasoning is: a) Students with high numerical reasoning reaches level 5, good in formulating with communicating, representation, and devising strategies for problem solving, employing with communicating, mathematising, representation, reasoning and argument, devising strategies for problem solving, using symbolic, formal, and technical language and operation, and using mathematics tools, and interpreting with communicating, representation, and devising strategies for problem solving; b) Students with medium numerical reasoning was reached level 4, good in fomulating with communicating, representation, and devising strategies for problem solving, employing with communicating and using symbolic, formal and technical language and operations and intepreting with communicating, representation, dan reasoning and argument; c) Students with low numerical reasoning at the level of 2 and 3, good in formulating with dasar representation dan devising strategies for problem solving, and employing with communicating and representation.

4. Ability mathematical literacy of students based on logical and numerical reasoning is: a) Students with high logical and numerical reasoning reached level 5, good in formulating with communicating, representation, and devising strategies for problem solving, 
employing with communicating, mathematising, representation, reasoning and argument, devising strategies for problem solving, using symbolic, formal, and technical language and operation, and using mathematics tools, and intepreting with communicating, representation, dan devising strategies for problem solving; b) Students with logical and numerical reasoning was reached level 3 and 4, good in formulating with communicating, representation, reasoning and argument, and devising strategies for problem solving, employing with communicating, and reasoning and argument, and intepreting with communicating, representation, dan reasoning and argument; c) Students with high logical and medium numerical reasoning and also medium logical and high numerical reasoning reached level 4 and 5, good in formulating with communicating, representation, and devising strategies for problem solving, employing with communicating, devising strategies for problem solving, using symbolic, formal, and technical language and operation, and using mathematics tool and interpreting with communicating, representation, reasoning and argument, dan devising strategies for problem solving; d) Students with low logical and numerical reasoning only in level 1 and 2, good in formulating with devising strategies for problem solving, employing with communicating, and interpreting with communicating, representation, and reasoning and argument.

Logic and numerical reasoning affects student ability to think, calculate and understand the problem so that it also affects the ability of students' mathematical literacy. The ability of the mathematical literacy should be owned by all students in order to understand and solve problems appropriately in order to future challenges.

Teachers should help strive for the achievement of these abilities. Teachers can use different ways to know and analyze students' literacy skills. One can develop instruments to analyze, measure, or identify students' mathematical literacy skills. In addition, teachers need to pay attention to these conditions in classroom learning activities. Different logical and numerical reasoning abilities allow different abilities of students' mathematical literacy. The ability of logical and numerical reasoning can be honed as well as the ability of mathematical literacy.

Teachers attention to differences in students' logical and numerical reasoning abilities will have implications for the selection of appropriate learning models. Model selection should be tailored to the characteristics of students' abilities. Learning with the right model and quality is expected to provide increased mathematical literacy skills.

\section{REFERENCES}

Adonis, A. (2006). Primary Framework for Literacy and Mathematics. United Kingdom: Department Education and Skills.

Bokar, A. J. (2013). Solving ang Reflecting on Real-World Problems: Their Influences on Mathematical Literacy and Engagement in the Eight Mathematical Practises. Thesis: Ohio University.

Diezmann, C. M., Watters, J. J., \& English, L. D. (2001). Implementing Mathematical Investigation with Young Children. Proceedings 24th Annual Conference of the Mathematics Education Research. Sydney: Group of Australia.

Dowden, B. H. (2011). Logical Reasoning. California: California State University Sacramento. 
Durrant-Law, G. (2013). Logical Thinking. Canberra: University of Canberra.

Kariadinata, R. (2012). Menumbuhkan Daya Nalar (Power Of Reason) Siswa Melalui Pembelajaran Analogi Matematik. Infinity, 1(1), 10-18. doi:10.22460/infinity.v1i1.3.

Kasihani, E. S. (2002). Contextual Learning and Teaching (CTL) (Pengajaran dan Pembelajaran Kontekstual). Prosiding Seminar Akademik, 2, 1-6.

Krause, J., Dias, L. P., \& Schedler, C. (2015). Krause, J., Dias, L.P., dan Schedler, C. Competency-Based Education: A Framework for Measuring Quality Courses. Online journal of Distance Learning administration Spring, 18(1), 1-9.

MacGregor, R. R. (2007). The Essential Practices of High Quality teaching and Learning. The Center for Educational Effectiveness, Inc.

Melville, W., \& Yaxley, B. (2009). Contextual Opportunities for Teacher Professional Learning: The Experience of One Science Department. Eurasia Journal of Mathematics, Science \& Technology Education, 5(4), 357-368.

Mulyatiningsih, E. (2010). Pembelajaran Aktif, Kreatif, Inovatif dan Menyenangkan (PAIKEM). Jakarta: Direktorat Jendral Peningkatan Mutu Pendidik dan Tenaga Kependidikan.

Murnane, R., Sawhill, I., \& Snow, C. (2012). Literacy Challenges for the Twenty-First Century: Introducing the Issue. The Future of Children, 22(2), 3-15.

OECD. (2013). PISA 2012 Assessment and Analytical Framework. OECD Publishing.

Ojose, B. (2011). Mathematics Literacy: Are We Able to Put The Mathematics We Learn Into Everyday Use? Journal of Mathematics Education, 4(1), 89-100.

Riyanto, B., \& Siroj, R. A. (2011). Meningkatkan Kemampuan Penalaran dan Prestasi Matematika dengan Pendekatan Konstruktivisme pada Siswa Sekolah Menengah Atas. Jurnal Pendidikan Matematika, 5(2), 111-127.

Rusmining, Waluya, S. B., \& Sugianto. (2014). Analysis of Mathematics Literacy, Learning Constructivism and Character Education (Case Studies on XI Class of SMK Roudlotus Saidiyyah Semarang, Indonesia). International Journal of Education and Research, 2(8), 331 - 340.

Sandstorm, M., Nilsson, L., \& Lilja, J. (2013). Displaying Mathematical Literacy-Pupils' Talk about Mathematical Activities. Journal of Curriculum and Teaching, 2(2), 55 - 61.

Shadiq, F. (2004). Pemecahan Masalah, Penalaran dan Komunikasi. Yogyakarta: PPPG Matematika Yogyakarta.

Stacey, K. (2012). The International Assessment of Mathematical Literacy: PISA 20112 Framework and Items. 12th International Congress on Mathematical Education. Seoul, Korea: Coex.

Suyono. (2009). Pembelajaran Efektif dan Produktif Berbasis Literasi: Analisis Konteks, Prinsip, dan Wujud Alternatif Sebagai Implementasinya di Sekolah. Bahasa dan Seni, 37(2), 203-217.

Turner, R. (2011). Exploring Mathematical Competencies. Research Development, 24(5), 1-6. 
110 Ni'mah, Junaedi \& Mariani, Mathematical Literacy's Vocational Students ...

Venkat, H., Graven, M., Lampen, E., \& Nalube, P. (2009). Critiquing the mathematical literacy assessment taxonomy: Where is the reasoning and the problem solving? Pythagoras, 0(70), 43-56. doi:10.4102/pythagoras.v0i70.38.

Wardhani, S., \& Rumiati. (2011). Modul Matematika SMP Program Bermutu Instrumen Penilaian Hasil Belajar Matematika SMP: Belajar dari PISA dan TIMSS. Jakarta: Kemendiknas dan PPPPTK. 